\title{
Legal Protection on Notary Related with Deeds which Made in Process of Police Investigation
}

\author{
Nopi Siswanti ${ }^{*}$ and Sri Endah Wahyuningsih ${ }^{* *}$ \\ $\left.{ }^{*}\right)$ Faculty of Law, Universitas Islam Sultan Agung (UNISSULA) Semarang, E-mail: \\ novisiswanti10@gmail.com \\ ${ }^{* *}$ Faculty of Law, Universitas Islam Sultan Agung (UNISSULA) Semarang, E-mail: \\ endah.w@unissula.ac.id
}

\begin{abstract}
The notary office law and the notary code of ethics require that notaries in carrying out their duties as public officials, in addition to being subject to the position of a notary, they must comply with the professional code and must be responsible to the people they serve. Notaries who neglect all dignity of their positions apart from being subject to moral sanctions, being reprimanded or dismissed from their organization can also be fired from their positions as notaries. In fact, not all notaries act fairly, are impartial, and protect the interests of the parties. This study wants to see how the different roles of Indonesian police investigators in handling criminal acts committed by notaries after the Constitutional Court Decision No. in legal protection for notaries related to the deed he makes, then see how the model of legal protection for notaries who commit criminal acts related to the deed he made after the Constitutional Court Decision No 49 / PUU-X / 2012 and Ministerial Regulation and Human Rights Number 7 of 2016. Research it uses a socio legal approaches. Socio legal research examines the implementation or implementation of positive legal provisions in fact at any particular legal event that occurs in society in order to achieve predetermined goals.
\end{abstract}

Keywords: Legal Protection; Investigation Process; Indonesian Police.

\section{Introduction}

Notary which has been described in the Law concerning the Regulation of Notary Position Number 30 of 2004 is stated in Article 1, the notion of a Notary is a public official who is authorized to make authentic deeds and other authorities as referred to in the law. Notary is a public official which means someone who is appointed, and given the authority and obligation by the state to serve the public in certain matters. Public officials are also people who carry out some of the state's public functions, especially in the field of civil law. 
Apart from being a public official, the authority in carrying out the position of a notary is also inseparable from the code of ethics because a notary is also a profession. Notaries always refer to the Law on Notary Positions and must act in accordance with their professional ethics. Professional ethics are ethical attitudes that are required to be fulfilled by professionals in carrying out their profession. Professional ethics are formally manifested into a code of ethics. Notaries with their position professional organizations describe professional ethics into the notary code of ethics.

A notary must adhere to the code of ethics for the position of a notary. The code of ethics is guidance, guidance, moral or decency guidelines for a profession or is a list of obligations in carrying out a profession which is compiled by members of the profession itself and binds them in practicing it. ${ }^{1}$ In fact, not all notaries can act honestly, fairly, impartially, and protect the interests of the parties. There are several notaries who do not comply with the Law on Notary Positions and the Notary Code of Ethics so that not a few notaries are involved in civil cases and some are even involved criminal case.

In the event that a notary is involved in a criminal case, it cannot be separated from the Regional Supervisory Council (MPD) or what is now called the Notary Honorary Council (MKN) and can then enter the realm of investigation in the police. In connection with the judicial process, especially those related to allegations of criminal acts against a notary, investigator, public prosecutor, or judge, in taking the minutes of deed and summoning a notary, it must first be approved by the Regional Supervisory Council. In the Law on the Position of a Notary, it is regulated in Chapter VII Article 66 and this is not delegated to another Supervisory Board. MKN decisions are final, except for supervision in general which is regulated in Chapter IX Articles 67 to 81 of the Law on Notary Positions. Supervision of notaries is carried out by the Minister of Law and Human Rights (Menkumham), and in carrying out such supervision, the minister forms a Supervisory Council (Article 67 of the Law on Notary Positions). In its development, the Regional Supervisory Council after the issuance of the Constitutional Court's decision no. 49/PUU-X/2012 because many notaries have expressed their disappointments personally or through social media as well as through professional organizations, this decision became a turning point in the notary's awareness that in fact the position of a notary is very vulnerable. The authority of the Regional Supervisory Council was amputated because of the Constitutional Court's decision. 49/PUU-X/2012 because many notaries have expressed their disappointments personally or through social media as well as through professional organizations, this decision became a turning point in the notary's awareness that in fact the position of a notary is very vulnerable. The authority of the Regional Supervisory Council was amputated because of the Constitutional Court's decision. 49/PUU-X/2012 because many notaries have

1 Liliana Tedjosaputro, Etika Profesi Notaris dalam penegakkan Hukum Pidana, (Yogyakarta; Bigraf Pulishing, 1995) p.29 
expressed their disappointments personally or through social media as well as through professional organizations, this decision became a turning point in the notary's awareness that in fact the position of a notary is very vulnerable. The authority of the Regional Supervisory Council was amputated because of the Constitutional Court's decision.

Before the Constitutional Court Decision No. 49/PUU-X/2012, it is very difficult to involve a notary in a legal case or case because of the obligation to submit an application to the Regional Supervisory Council first. Case examination by the Regional Supervisory Council is the main thing in summoning a notary by investigators, public prosecutors, and judges. After the Constitutional Court Decision No. 49/PUU-X/2012, there are many notaries who are very worried about the risks of work, duties, and positions.

It can be seen that there are not a few disappointments and concerns over the notaries who ignore and neglect the rules that apply in carrying out their positions. Some of the problems that exist in the lack of knowledge and skills of notarial law, lack of professionalism in providing legal services, the potential for incoherence in carrying out positions with alleged price wars that result in a decrease in the economic value of a deed, and many other problems.

The internal problems of the notary position often make the position of the notary in legal problems, both civil and criminal law problems. Many people question where is the role of notary organizations in improving these kinds of things. This condition must receive serious attention from notaries to restore the dignity of notaries. ${ }^{2}$

Departing from this reality, Act No. 2 of 2014 was born, which is an amendment to Act No. 30 of 2004 concerning the Position of Notary. This amendment then re-presents the principle of protection for the position of a notary with a new nomenclature called the "Notary Honorary Council". However, Tomson Situmeang in his capacity as an advocate feels that his constitutional rights have been harmed by the enactment of Article 66 paragraph (1), along with the approval of the Notary Honorary Council, paragraph (3) and paragraph (4) of the Notary Position Act. He feels that this provision has implications for the loss of integrity, legal services involving advocates, so that legal services will decline and public trust in law enforcement will be lost. Then he submitted a judicial review of Article 66 (1), (3).

The decision of the Constitutional Court in Case Number 72/PUU-XII/2014 stated that the petition of the petitioner could not be accepted, because there were no real or potential constitutional losses with the entry into force of the article being tested. The Constitutional Court considers that an application by profession as an advocate is even more secure and their rights protected by the presence of the Notary Honorary Council, when an Indonesian citizen submits a

\footnotetext{
${ }^{2}$ zulpiero.wordpress.com.relationship-regulation-notary-position-and-code-of-ethics-inimplementation-of-notary-duties.
} 
request to be presented with evidence in the form of a photocopy of the minutes of the deed or a notary. ${ }^{3}$

The existence of Article 66 Paragraph (1) of Act No. 2 of 2014 concerning the Position of a Notary, is supported by the issuance of the Decision of the Constitutional Court Number 49/PUU-X/2013 dated 28 May 2013 and the Regulation of the Minister of Law and Human Rights Number 7 of 2016 concerning the Honorary Council of Notaries, it removes the Notary's Privilege in providing information to the police. The main reason for the Constitutional Court regarding the prohibition of requests for MPD approval for summons and examination of Notaries both as witnesses and suspects, which is considered to be contrary to Article 27 paragraph (1) and Article $28 \mathrm{D}$ paragraph (1) of the 1945 Constitution, and the second reason is that it has no power. So that the notary who initially can refuse before the MPD approval.

Guided by the problems that have been stated previously, especially the problem regarding the different roles of police investigators in terms of Article 66 paragraph (1) of Act No. 2 of 2014 concerning the Position of a Notary, thus encouraging researchers to put more emphasis on research on how the mechanism of legal protection by police investigators against Notaries who commit criminal acts in terms of the existence of Article 66 paragraph (1) of Act No. 2 of 2014 concerning Notary Positions, Constitutional Court Decision Number 49/PUU-X/2013 dated 28 May 2013, and Regulation of the Minister of Law and Human Rights Number 7 of 2016, revoked Article 66 paragraph (1) of the Law on Notary Positions Number 30 of 2004 . This problem is also directly related to the invalidation of the provisions in Article 14 paragraph (1) of the Regulation of the Minister of Law and Human Rights of the Republic of Indonesia Number M.03HT. 3.10.2007 concerning Minutes of Deed and Summons of Notaries.

Based on the above background, the formulation of the problem in this study are: 1) What are the differences in the roles of investigators from the Indonesian National Police in handling crimes committed by notaries after the Constitutional Court Decision No. 49/PUU-X/2012 and Regulation of the Minister of Law and Human Rights Number 7 of 2016? 2) What is the impact of the different patterns of investigation by the National Police in handling criminal acts committed by a notary on legal protection for a notary related to the deed he made? 3) How is the legal protection for a Notary related to the deed he made in the investigation process at the Indonesian National Police Agency?

\section{Research Methods}

This study uses the type of socio legal research. Socio legal is an approach that is carried out by looking at the legal reality in society, and is an approach used to

${ }^{3}$ www.mahkamahkonsstitution.go.id/28August2015. 
see legal aspects in social interaction in society, functioning as a support to identify findings of non-legal materials for research purposes or legal writing. ${ }^{4}$ This descriptive socio-legal research is reinforced by prescriptive interpretation analysis, which is a method of finding law by interpreting/interpreting/prescriptive where this method aims to study symptoms with an interpretation approach and legal construction by analyzing in depth which means describing ideal conditions (das sollen) with existing conditions (das sein), then if there are deviations or gaps, then analyzed with theory and hermeneutic interpretation (this is what is meant by perspective). ${ }^{5}$

Data collection techniques used in this research are literature study and interviews, namely data collection by reading laws and regulations, official documents and literature that are closely related to the problems discussed based on secondary data and conducting interviews so that verbal interactions occur, directly between the interviewer and the respondent.

\section{Results and Discussion}

3.1. Differences in the Role of Police Investigators in Handling Crimes by Notaries after the Constitutional Court Decision No. 49/PUU-X/2012 and Regulation of the Minister of Law and Human Rights Number 7 of 2016

The difference in the role of investigators at the Resort Police in summoning and examining notaries both as witnesses and suspects of criminal acts, after the issuance of the Constitutional Court Decision Number 49/PUU-X/2012 is the same as the summons and examination process according to Article 66 paragraph (1) of the Law. Number 2 of 2014 concerning the Position of a Notary, that is, there is no need to seek approval from the Regional Supervisory Council (MPD) but to seek approval from the Notary Honorary Council (MKN).

Based on these differences, the authors will analyze them by utilizing the theory of the work of law, namely that in the examination of a notary who is reported to have committed a criminal act, it is regulated in Article 66 paragraph (1) of Act No. 2 of 2014 concerning Notary Positions. However, the summons is regulated in more detail in the Regulation of the Minister of Law and Human Rights Number: M.03.HT.03.10 of 2007 concerning Taking Minutes of Deeds and Summons of Notaries. The summons procedure is regulated in CHAPTER IV Article 14 concerning the Terms and Procedures for Summoning a Notary, which states:

\footnotetext{
${ }^{4}$ Mukti Fajar Nur Dewata and Yulianto Achmad, Dualisme Penelitian Hukum Normatif dan Empiris (Yogyakarta; Pustaka Pelajar, 2010), p. 104

5 Widhi Handoko, Contoh Penulisan Proses Penelitian Dalam Metode Penelitian, widhihandoko.com/?tag=socio-legal, accessed on October 13, 2016
} 
a. Investigators, Public Prosecutors or Judges for the purposes of the judicial process may summon a notary as a witness, suspect or defendant by submitting a written application to the Notary Honorary Council.

b. The copy of the application as referred to in paragraph (1) shall be submitted to a notary.

c. The application as referred to in paragraph (1) contains the reasons for summoning a notary as a witness, suspect or defendant.

The summons will not be immediately approved by the Notary Honorary Council (MKN). MKN will study the summons and conduct an examination of the notary concerned. If it turns out that during the examination, an error in the procedure for making the deed is found, the MKN will give approval for the summons to the police against the notary. Furthermore, if during the examination there are no deviations from the procedure for making the deed, then the MKN has the authority not to give approval for the summons to the notary. Consent will be given by means of an official written reply.

Article 15 of the Regulation of the Minister of Law and Human Rights states that the MKN will give approval to summon a notary if there is an alleged criminal act related to the minutes of the deed and/or documents attached to the minutes of the deed or the protocol of the notary in the notary's deposit or the right to sue based on provisions regarding expiration in the laws and regulations in the criminal field.

A summons made by an investigator is considered valid and perfect, so it must meet the following requirements:

a. The investigator states the reasons for the summons clearly by taking into account the reasonable timeframe for receiving the summons and if it does not come, the investigator may summon once again to appear before the investigator as regulated in Article 112 of the Criminal Procedure Code;

b. If the suspect and witness reside outside the investigator's jurisdiction, the examination may be conducted at the suspect's or witness's residence as regulated in Article 119 of the Criminal Procedure Code;

c. The summons is carried out no later than 3 days in advance as stipulated in Article 227 of the Criminal Procedure Code.

The provisions of Article 16 paragraph (1) letter 1 of Act No. 2 of 2002 concerning the Indonesian National Police (Polri) authorize the National Police as investigators to take responsible actions according to law. Provisions of Article 6 paragraph (2) The Law on the National Police stipulates that what is meant by responsible actions according to law are: 
a. Not against a rule of law;

b. In accordance with the legal obligation that requires the action to be carried out;

c. Must be appropriate, reasonable, and included in the investigator's office environment;

d. Appropriate consideration based on compelling circumstances;

e. Respect human rights.

The actions mentioned above must be carried out by investigators in every investigation process. During the investigation process, there are several parties who will be questioned, including witnesses and suspects. What is meant by witnesses in criminal cases relating to the formal aspects of the notary deed, the investigators, public prosecutors and judges will include notaries who have taken legal actions:

a. Making fake/forged letters and using fake/forged letters (Article 263 paragraph (1), (2) of the Criminal Code).

b. Doing forgery (Article 264 of the Criminal Code).

c. Ordered to include false information in an authentic deed (Article 266 of the Criminal Code).

d. Doing, ordering to do, participating in doing (Article 55 in conjunction with Article 263 paragraphs (1) and (2) or Article 264 or 266 of the Criminal Code).

e. Assist in making fake/falsified documents (Article 56 paragraphs (1) and (2) in conjunction with Article 263 paragraph (1) and (2) or Article 264 or 266 of the Criminal Code).

Examination of a notary as a suspect or defendant must be based on the procedures for making a notary deed, namely:

a. Conduct an introduction to the appearer, based on his/her identity shown to the notary.

b. Asking questions, then listening and paying close attention to the wishes or wishes of the parties (questioning and answering).

c. Examine the documentary evidence relating to the wishes or wishes of the parties.

d. Provide advice and create a deed framework to fulfill the wishes or wishes of the parties.

e. Fulfill all administrative techniques for making a notarial deed, such as reading, signing, providing copies, and filing for minutes.

f. Perform other obligations related to the implementation of the duties of a notary public. 
Considering in Article 66 UUJN Number 2 of 2014, it is not explained in what status a notary can be summoned by an investigator, public prosecutor or judge, then the question arises "whether the approval of the summons of a notary as referred to in Article 66 is only limited to his position as a witness, both in cases of civil, criminal or administrative/state administration or is it also included as a suspect in a criminal case or as a defendant or co-defendant in civil cases?". With regard to the opinion of the Central Supervisory Council as described above, it is understood that:

a. Whether in status as a witness or suspect in connection with a deed made by or before him or with a notary protocol in its storage, the summons of a notary requires prior approval from the Notary Honorary Council;

b. The purpose of summoning a notary is to find legal facts that have an important influence in the judicial process, so that the summons process is expected to help facilitate the judicial process, as stated in the third consideration of the Central Supervisory Council letter above, so in the process of granting approval, opinions must be avoided or at least the impression that the Honorary Council of Notaries conducting the examination hinders the granting of the said approval.

In the event that the summons of a notary is intended as a witness to the deed he made, before granting permission, the MKN must first look at the nature of the deed for which information is requested from the notary making the deed, namely if the deed is are:

a. Verbal acte or ambtelijke acte can also be referred to as a testimony deed from a notary as a public official. As a deed which is a testimony from a notary, the notary is fully responsible for the contents of the deed. The contents of the verbal act are sometimes not able to provide an overview of a legal event that has been experienced, seen or witnessed by the notary making the deed. In addition, the contents of the verb acte can also not be understood, so additional information is still needed. In such case, only the notary making the verbaal act can provide the necessary additional information. Therefore, if there is a request as referred to in Article 66 of the UUJN Number 2 of 2014 related to a verbaal act, it is appropriate that the MKN gives its approval.

b. Partij acte or a deed of appearance, in a partij acte notary only puts what the parties want as an appraiser into an authentic deed. In other words, in the partij acte the notary only formulates the will of the parties and then pours it into the deed. The notary in the partij acte is only responsible for the beginning and end of the deed, while the contents of the deed are the full responsibility of the parties in the deed. 
The process of summoning and examining a notary as a witness or suspect in a criminal act is the same as the process of summoning and examining according to Article 66 paragraph (1) of Act No. 2 of 2014 concerning the Position of a Notary, that is, there is no need to ask for approval from the Notary Supervisory Council (MPN) but seek approval from the Notary Honorary Council (MKN). However, it is different after the decision of the Minister of Law and Human Rights, namely the consideration of the decision of the Constitutional Court Number: Minister of Law and Human Rights Regulation number 7 of 2016.

\subsection{The Impact of Differences in Investigation Patterns by the Police in Handling Crimes Perpetrated by Notaries on Legal Protection for Notaries Related to the Deed Made}

A notary as a trusted public official whose deeds can be strong evidence in the event of a legal dispute in court, a notary must uphold the dignity of his profession as a position of trust and carry out his duties appropriately and honestly, which means acting according to the truth in accordance with notary oath.

A notary is also a human being who does not escape from mistakes, whether intentional or due to negligence. This condition is also exacerbated by the large number of notaries who are in each working area so that it is possible for violations of the making of the deed to occur. Every act that violates the law must of course undergo a process of investigation, investigation, and trial as well as other legal processes, both civil and criminal. Associated with such matters, often these problems fall into the realm of criminal law. Of course, this legal dispute does not only have implications for the Notary who made the deed, but can also have implications for the deed itself.

Therefore, the need for summons and the presence of a notary in the examination of a criminal case can be distinguished as follows: ${ }^{6}$

\section{a. As an Expert}

In this case a notary is summoned and his presence in criminal case examinations is necessary as a legal expert who is authorized to make an authentic deed so that special legal considerations are needed according to his expertise related to the authority and responsibility of a notary as well as matters that can provide explanations to Polri investigators, Public Prosecutors, judges, lawyers/legal advisors and justice seekers.

b. As a Witness

In this case, a notary is summoned and his presence in the examination of a criminal case is required, in his capacity as a public official who makes an

${ }^{6}$ Hakim Amrie,"Unsur - Unsur Pidana yang Dihadapi Notaris dalam Menjalankan Jabatannya" 
authentic deed, his testimony is needed against what he saw, heard and supporting evidence in making the authentic deed, which turned out to be a criminal case. In this position as a witness, if there is a strong suspicion that a notary is involved, his status can be increased to become a suspect.

c. As a suspect

In this case, a notary is summoned and his presence in a criminal case examination is necessary as a suspect based on preliminary evidence so that it is reasonable to suspect that there was a crime committed by a notary as an authentic deed maker, either alone or jointly, which was found by the investigator, so that the notary must be held accountable for the act in court.

With regard to a notary who is a defendant in a criminal case, for this reason, the author proposes a comparison of the form of legal protection before the Constitutional Court Decision Number 49/PUU-X/2012, with the form of legal protection after the issuance of the Constitutional Court's decision, which is as follows:

\subsection{Notary Legal Protection Prior to the Constitutional Court Decision Number 49/PUU-X/2012 dated 28 May 2013}

Legal protection for the position of a notary in carrying out his duties as a public official has been regulated in Act No. 30 of 2004 concerning the position of a notary. Specifically related to the making of a deed carried out by a notary, the Law on Notary Position provides legal protection to a notary as contained in the provisions of Article 4 paragraph (2) concerning the Oath/Promise of a Notary, one of which reads "...that I will keep the contents of the deed and the information obtained confidential in the performance of my office...".

It is further regulated in the provisions of Article 16 paragraph (1) letter e, which reads "...In carrying out his office, a Notary is obliged to: e. keep everything regarding the deed he made and all information obtained for making the deed in accordance with the oath/promise of office, unless the law stipulates otherwise...". However, this limitation of "...the law provides otherwise..." is not found to be regulated. Even Act No. 8 of 1981 concerning Criminal Procedure Code, provides an opportunity for someone to be released from the obligation to provide information because of work, dignity or position, they are required to keep secrets.

Likewise, the provisions of Article 1909 paragraph (2) of the Civil Code and the provisions of Article 322 paragraph (1) of the Criminal Code. However, if these provisions are understood, then what must be kept confidential are only those that are entrusted to him because of his position, work and position. Legal 
protection for notaries in carrying out their duties as Public Officials is regulated in Act No. 30 of 2004 concerning Notary Positions, which are specifically related to the making of deeds as regulated in the provisions of Article 4 paragraph (2) and Article 16 paragraph (1) letter e regarding the obligation of a notary to maintain the confidentiality of the deed he made is to protect the interests of all parties related to the deed he made. Therefore, in accordance with the provisions of Article 16 paragraph (1) letter b, a notary is obliged to make a deed in the form of a minutes of deed and keep it as part of the notary protocol. This is intended to maintain the authenticity of a deed. So that if there is forgery or misuse, grosse, copies, or quotations can be easily identified by matching them with the original. Notaries can only provide, show, or notify the contents of the deed, grosse deed, copy of the deed or excerpt of the deed, to people who have a direct interest in the deed, heirs, or people who have rights, unless otherwise stipulated by laws and regulations, this is in accordance with with the provisions of Article 54 of Act No. 30 of 2004 concerning the Position of a Notary.

In giving, showing, or notifying the contents of the deed, a notary can give, show, or notify: ${ }^{7}$
a. Persons with direct interest in the deed;
b. Heir; or
c. People who have rights.

Legal protection for the notary is also regulated technically in the Regulation of the Minister of Law and Human Rights Number: M.03.HT.03.10 of 2007. In CHAPTER III of the Minister of Law and Human Rights, it is regulated on the Terms and Procedures for Taking Minuta of Deeds and/or Letters Placed on the Minutes of Deed or Notary Protocol in the Notary's Depository.

\subsection{Model of legal protection for notaries who commit crimes related to the deed made after the decision of the Constitutional Court No. 49/PUU- $\mathrm{X} / 2012$ and Regulation of the Minister of Law and Human Rights Number 7 of 2016}

The model of legal protection for notaries who carry out according to the author's research is that before the decision of the Constitutional Court NO 49/PUU-X/2012 is the same as the Minister of Law and Human Rights Regulation number 7 of 2016, that the legal efforts of the Notary Supervisory Council (MPN) for summons and examination by Polri investigators against notaries who commit criminal acts, namely by providing legal protection. Legal protection for notaries in carrying out their duties as Public Officials, both before and after the Decision of the Constitutional Court of the Republic of Indonesia Number 49/PUU-X/2012, dated 28 May 2013 is the SAME, as stipulated in Act No. 30 of

\footnotetext{
${ }^{7}$ Soerjono Soekanto, Pengantar Penelitian Hukum, Ed. 3,(Jakarta; UI Oress,2004)
} 
2004 concerning Positions. Notary and related to the making of the deed carried out by a notary, The Notary Position Act provides legal protection to notaries as contained in the provisions of Article 4 paragraph (2) regarding the Notary Oath / Promise, one of which reads "...that I will keep the contents of the deed and information obtained in the exercise of my position secret...". It is further regulated in the provisions of Article 16 paragraph (1) letter e, which reads "...In carrying out his/her position, a Notary is obliged to: e. keep everything about the deed he made and all information obtained for the making of the deed in accordance with the oath/promise of office, unless the law stipulates otherwise...".

However, what is different is the procedure for legal protection of a notary in carrying out his duties as a public official. Based on the Decision of the Constitutional Court of the Republic of Indonesia Number 49/PUU-X/2012, dated May 28, 2013, the procedures stipulated in Article 66 paragraph (1) of the Law on Notary Positions are technically regulated in the Regulation of the Minister of Law and Human Rights Number: M.03.HT.03.10 Year 2007 is no longer valid. Investigator or Public Prosecutor or Judge in taking a photocopy of the Minutes of Deed and/or letters attached to the Minutes of Deed or Notary Protocol in the notary's depository; and summoning a notary to attend an examination related to the deed he made or the Notary Protocol that is in the notary's deposit is no longer necessary "with the approval of the Regional Supervisory Council".

This is actually not something to be worried about, if the notary in carrying out his duties acts in accordance with the applicable laws and regulations and in accordance with the existing code of ethics. In addition, the notary also still has the "RIGHT to deny" which is also the "Obligation to deny" in dealing with the efforts of interested parties, including investigators, public prosecutors or judges. The right of refusal is the right owned by a notary not to answer questions from investigators, public prosecutors, or judges, when examined or asked for information on problems that arise in the notarial deed he made. information before investigators, public prosecutors or judges related to the secret of his position, namely regarding matters entrusted to him because of his position, work and position, based on the provisions of Article 170 paragraph (1) of the Criminal Code, Article 1909 of the Civil Code and the provisions of Article 322 paragraph (1) KUHP.

Based on The right of denial, the notary can still maintain the confidentiality of everything regarding the deed he made and all information obtained for the making of the deed. There are concerns from the notary community about "arbitrary actions" from unscrupulous investigators, it is better to make a rule regarding the procedure for summoning and examining notaries, either as witnesses or suspects. This is also in line with the Memorandum of Understanding (MoU) between the Indonesian National Police (Polri) and the Indonesian Notary Association (INI) No. Pol: B/1056/V/2006 and Number: 01/MOU/PP-INI-/V/2006 concerning Development of Professionalism 
Improvement in the Field of Law Enforcement, dated May 9 2006, in particular the provisions of Article 1 paragraph (2) which states that legal actions taken by investigators (Investigators) as referred to in paragraph (1) in the form of summons, examination.

\section{Conclusion}

1) After the issuance of MK Decision Number 49/PUU-X/2012, the investigator, in summoning and examining a notary suspected of committing a crime related to his authority as a notary, is in accordance with Article 66 paragraph (1) of Act No. 2 of 2014 concerning Notary position, which is no longer necessary to ask for approval from the Regional Supervisory Council (MPD). However, with the Regulation of the Minister of Law and Human Rights Number 7 of 2016 again, the investigator process in summoning a Notary must be with the permission of the MKN. 2) Every unlawful act, including unlawful acts committed by a notary, must of course undergo a process of investigation, investigation and trial as well as other legal processes, both civil and criminal. Of course, this legal dispute does not only have implications for the notary who made the deed, but can also have implications for the deed itself. Therefore, there is a need for legal protection for notaries through MKN which can be carried out repressively because it is related to the application of Article 66 paragraph (1) of Act No. 2 of 2014 concerning Notary Positions, namely in giving approval or rejecting requests for investigators who want to summon a notary in the process. Justice. The existence of this MKN basically replaces the role of the MPD as a legal protection institution for notaries. 3) The protection model for notaries after the Constitutional Court Decision Number 49 of 2012 and Permenkumham Number 7 of 2016 is as follows: MKN can still provide legal protection to Notaries who are in conflict with the law through the means of giving approval contracts while still coordinating with the police investigators, When investigating or summoning a notary, the police investigators may not be able to directly without notification to MKN, and POLRI investigators, MKN, and INI can form a special forum as a forum for dialogue to discuss several important decisions related to notaries who are in conflict with the law.

\section{References}

Books:

[1] Amirudin and H. Zaenal Asikin, Pengantar Metode Penelitian Hukum (Jakarta: RajaGrafindo Persada, 2008)

[2] Banakar, Reza and Max Travers, Law, Sociology and Method dalam Reza Banakar \& Max Travers (ed), Theory and Method in Socio-Legal Research,(Onati: Hart Publishing Oxford and Portland Oregon, 2005) 
[3] Hakim Amrie,"Unsur - Unsur Pidana yang Dihadapi Notaris dalam Menjalankan Jabatannya"

[4] Mahmud Peter Marzuki, Penelitian Hukum, ed. 1, ( Jakarta: Prenada Media, 2005)

[5] Mukti Fajar Nur Dewata and Yulianto Achmad, Dualisme Penelitian Hukum Normatif dan Empiris (Yogyakarta; Pustaka Pelajar, 2010)

[6] Rosady Ruslan, Metode Penelitian Public Relations dan Komunikasi, (Jakarta: Rajawali Pers, 2003)

[7] Soerjono Soekanto, Pengantar Penelitian Hukum, ed. 3,(Jakarta; UI Oress, 2004

[8] Suteki, Desain Hukum di Ruang Sosial, Thafa Media, Yogyakarta, 2014

[9] Tobing, Lumban S.H., Peraturan Jabatan Notaris, Erlangga, Bandung, 1983.

[10] Tedjosaputro, Liliana, Etika Profesi Notaris dalam penegakkan Hukum Pidana,(Yogyakarta; Bigraf Pulishing, 1995)

[11] Widhi Handoko, Contoh Penulisan Proses Penelitian Dalam Metode Penelitian, widhihandoko.com/?tag=socio-legal, Accessed on 13 October 2016

Regulation:

[1] Act No. 2 of 2014 concerning Amendments to Act No. 30 of 2004 concerning the Position of Notary.

[2] Civil Code

[3] Constitutional Court Decision No. 49/PUU-X/2013.

[4] Criminal Code

[5] Minister of Law and Human Rights Regulation No. 7 of 2016.

[6] Regulation of the Minister of Law and Human Rights Number: M.03.HT.03.10 of 2007 concerning the Taking of Minutes of Deed and Summoning of Notaries.

Internet:

[1] zulpiero.wordpress.com.relationship-regulation-notary-position-andcode-of-ethics-in-implementation-of-notary-duties. 
[2] http://www. Hukumonline.com/klinik/detail/cl5135/element-pidanayang-dihadapi-notaris-dalam-menjalankan-jabatannya,

[3] www.mahkamahkonsstitution.go.id/28August2015. 